\title{
Translanguaging and plurilingual texts as a resource in superdiverse classrooms
}

\author{
Lena Schwarzl and Eva Vetter \\ lena.schwarzl@univie.ac.at \\ UNIVERSITY OF VIENNA
}

\begin{abstract}
This contribution draws on the preliminary results of a project that uses translanguaging and plurilingual texts during an intervention (of six months) in one primary and one lower secondary school class in Vienna. Although Viennese pupils' linguistic repertoires are highly diverse, pupils usually barely get a chance to use their respective repertoires at school, because of a focus on highly prestigious languages, such as German or English. We assumed that pupils would positively experience the use of their plurilingual competences to gain self-efficacy. Moreover, we expected that group dynamics would improve due to the use of translanguaging. Results of the ethnographic observations and interviews we conducted with one teacher at each school at the end of the intervention are discussed in this article. They support the conclusion that school classes that are linguistically diverse benefit from intervention at the socioemotional level. However, it is crucial that teachers pay particular attention to the integration of less dominant languages.
\end{abstract}

Key words: translanguaging pedagogy, plurilingual texts, linguistic superdiversity, self-efficacy, dominant languages

\section{Résumé}

Cet article traite des résultats préliminaires d'un projet dans lequel des pratiques translangagières et des textes plurilingues ont été utilisés lors d'une intervention dans deux classes (en primaire et dans le secondaire) à Vienne. Bien que le répertoire linguistique des élèves soit extrêmement diversifié, ceux-ci ne l'utilisent que rarement à l'école en raison de la prédominance de l'allemand ou de l'anglais. Nous considérons que les élèves gagneraient en efficacité personnelle en utilisant leur répertoire linguistique. De plus, les pratiques translangagières semblent avoir un impact positif sur l'ambiance de classe. Cette contribution montre les premiers résultats des observations ethnographiques et des entretiens menés avec une enseignante de chacune des deux classes à la fin de la période d'intervention. Ces résultats permettent d'affirmer que les classes ayant une diversité linguistique profitent de l'intervention au niveau socio-émotionnel. Toutefois, il est indispensable que les enseignants intègrent bien les langues moins dominantes. 
Mots-clés : pédagogie translanguagière, texte plurilingue, superdiversité linguistique, efficacité personnelle, langues dominantes

\section{Introduction}

The present contribution draws on a larger project (Schwarzl, forthcoming) that originated from a cooperation between the University of Vienna, a primary (4th grade), and a lower secondary (5th grade) school class in Vienna. The overall aim of this project is to better understand the interplay between translanguaging in the classroom and the self-efficacy of pupils. In the present paper, we focus on some aspects of this interaction.

From September 2017 to February 2018, an intervention was carried out, during which pedagogical translanguaging (Cenoz, 2017), to be discussed in more detail in the next section, was integrated into several lessons of the two participating classes in order to enable pupils to use their linguistic repertoires during classes. The two school classes studied in the project were selected randomly, knowing that many pupils in Viennese primary and lower secondary schools use languages other than German (the language of schooling) in their family surroundings. Altogether 45 pupils aged 9-12 participated in the project. In the primary school, pedagogical translanguaging was used in the following subjects: German, Mathematics, Music, and Science (Sachunterricht). In the lower secondary school, it was used in German, Music, Sociology (soziales Lernen), and Geography lessons. Following an ethnographic approach, we regularly observed not only the listed subjects but also other subjects, breaks, and excursions. We decided to also observe lessons in which translanguaging was not used in order to discover whether the pupils might also use spontaneous translanguaging.

Before the intervention began, a meeting with the collaborating teachers (one teacher in the primary and five teachers in the lower secondary school) was organized. In this meeting, the concept of translanguaging was explained with respect to concrete examples from classroom instruction, focusing on the use of plurilingual texts and on texts in different languages (see next section for more details). Mostly, we provided the teachers with the magazine Trio, which was developed by the Austrian Ministry of Education (Austria, Bundesministerium ..., n.d., "Schule mehrsprachig"). Trio mainly consists of texts in German, Bosnian, Croatian, Serbian, and Turkish. Some of the magazine's issues also include texts in additional languages. Moreover, we had looked for several plurilingual books and books in different languages in a Viennese public library ${ }^{1}$ with a large selection of plurilingual books. The plurilingual texts

\footnotetext{
${ }^{1}$ buechereien.wien.gv.at/B\%C3\%BCchereien-Wien/Standorte-\%C3\%96ffnungszeiten/

Zweigstellen/Kinderb\%C3\%BCcherei-der-Weltsprachen
} 
were shown to the participating teachers during the first meeting, and it was suggested how and in which situations they could use them (for example, during partner or group activities, text-based input in different languages, oral and/or written translation-work). We asked them to regularly provide us with their monthly lesson preparations in order to allow us to prepare plurilingual texts in the topics they were planning to elaborate on with their pupils. Nevertheless, the teachers were told to feel free to use pedagogical translanguaging (Cenoz, 2017) and the plurilingual texts whenever they preferred. Furthermore, they were encouraged to create plurilingual contexts for learning (e.g., partner or group activities).

On the one hand, the intervention was intended to enable pupils to experience their linguistic repertoires as a potential resource and capacity. We assumed that this experience would influence their self-efficacy, explained further below, with respect to their linguistic repertoires. On the other hand, we expected that group dynamics would be affected by the use of translanguagingbased partner and group activities. To gather data, we used a qualitative design, consisting of ethnographic observations and interviews with one teacher at each school. In the following section, we discuss our view of translanguaging in the context of this research project.

\section{Translanguaging and plurilingual texts as a resource in classroom education}

From the theoretical perspective, the intervention is informed by a plurilingual approach to language in line with the definition given in the Common European Framework of Reference for Languages (Council of Europe, 2001). Hence, we assume that communicative language competence is composed of an individual's entire knowledge and experience of language. This approach foregrounds the interaction and interrelationship between languages. The concept of plurilingual competence relates to a large body of research (Coste, Moore, \& Zarate, 2009) and meets with research into the plurilingual repertoire (Blommaert \& Backus, 2011). Although the distinction between multilingualism (i.e., the separated co-existence of different languages) and plurilingualism( i.e., the interrelatedness of languages) is not shared by all researchers, we do believe that the theoretical conception of plurilingual competence fits particularly well with translanguaging, which foregrounds the interrelatedness of languages at the level of linguistic practice. Here, we draw on work that conceives of translanguaging as a linguistic practice that goes beyond a single language and includes all resources available within the plurilingual repertoire (García \& Kleyn, 2016).

As García (2017) states, translanguaging pedagogy has five major purposes. First, translanguaging serves as a resource to assist and motivate learn- 
ing, deepen meaning and understanding; second, to raise metalinguistic awareness, which is not focused on in this study; third, to strengthen bilingual identities; fourth, to contribute to better social interaction and communication and, fifth, for pupils' empowerment (p. 261). ${ }^{2}$ Moreover, García and Kleyn stress that translanguaging can contribute to perceiving different languages equally with regard to their prestige (García \& Kleyn, 2016), which is also of great relevance in our context. We further draw on Cenoz, Gorter, and May's (2017) descriptions of pedagogical and spontaneous translanguaging. Pedagogical translanguaging consists of the tasks set during lessons, which are planned and organized by teachers, whereas spontaneous translanguaging is defined as fluid discursive practices that naturally occur in and outside the classroom while pupils communicate with each other. Translanguaging at school potentially enables pupils to experience their plurilingual competence as a useful resource of which they can be proud. In the following section, we explain the concept of self-efficacy (Bandura, 1995, 1997), which is the second key concept informing the present work.

\section{Self-efficacy beliefs of pupils}

Our study incorporates this concept because we assume that pupils usually do not have strong feelings of self-efficacy regarding their plurilingual competences due to the fact that the languages they bring with them differ from those focused on by the Austrian school system. We have also learned that pupils who use languages other than German in their family surroundings and pupils with a migratory background suffer disproportionately often from early-school dropout (see section below on superdiversity).

In his socio-cognitive theory, Bandura describes the beliefs and convictions related to dealing with challenging or/and new tasks as self-efficacy (Bandura, 1995, 1997; Schwarzer \& Jerusalem, 2002): the stronger the conviction, the higher the self-efficacy (Bandura, 1995, Jerusalem, 2002). Moreover, selfefficacy can be perceived in two ways: as overall or general self-efficacy and as specific self-efficacy (Schwarzer \& Jerusalem, 2002), focusing on specific areas, such as, in this study, self-efficacy regarding pupils' plurilingual competences. Among other things, enhanced feelings of self-efficacy lead to a high level of motivation, the successful fulfillment of ones' educational or academic career, and the development of an intrinsic interest in life-long learning (Bandura, 1997). People with high self-efficacy are described as more effective in setting and pursuing goals; moreover, they set higher goals for themselves, they are more persistent and make higher efforts in executing tasks, and they are

\footnotetext{
${ }^{2}$ It has to be mentioned that García uses "bilingual" for phenomena that we understand here as "plurilingual" according to the definition above.
} 
more flexible and more resistant to distress in case of failure (Bandura, 1997; Schwarzer \& Jerusalem, 2002). Additionally, they usually do not attribute mistakes to personal failure but to external, controllable circumstances. This way of thinking permits them to recover quickly from negative experiences and to efficiently concentrate on task fulfillment (Bandura, 1997).

Bandura (1997) points out that school plays a decisive role in the development of self-efficacy. He stresses that children in cooperative classroom arrangements develop high self-efficacy more easily than children in competitive classroom arrangements. This corresponds to the idea that in the latter, social comparison is more dominant. Especially for lower-achieving children, social comparison negatively contributes to how they perceive themselves in comparison to higher-achieving children in class (Marsh, 1987).

Bandura (1997) distinguishes four sources that contribute to the development of self-efficacy:

- one's own experiences (mastery experience)

- experiences of peers (vicarious experience)

- verbal persuasion (we also included non-verbal persuasion)

- emotional arousal (p. 106)

Identifying the occurrence of these sources was one of the aims of our ethnographic observations, which introduces a new way of studying this construct in the field.

\section{The research questions}

The following research questions informed the work presented here:

1. How are translanguaging and plurilingual texts used in class?

2. How do teachers perceive the use of translanguaging and plurilingual texts in class?

3. Which factors seem to encourage or discourage the use of translanguaging and plurilingual texts in the classroom and what impact does it seem to have on the students' self-efficacy?

\section{The superdiversity of Viennese schools - opportunity or challenge?}

The proportion of pupils using different languages (often together with German) at home is very high in Vienna and these pupils' linguistic repertoires are highly diverse. Due to transmigration, this heterogeneity has increased, particularly in urban spaces (Busch, 2017). Austrian public schools usually have monolingual educational curricula and do not engage actively with this linguistic variety (Herzog-Punzenberger, 2017). It can be concluded that the monolingual habitus (Gogolin, 2008) is still evident. The following statistical overview 
shows the proportion of pupils in Vienna who, in their family surroundings, either use only languages other than German or use them in addition to German (Austria, Statistik Austria, 2019):

- primary schools: $58.8 \%$ of pupils (ages 6 to 10 )

- lower secondary schools (New Middle School): $74.5 \%$ of pupils (ages 10 to 14$)$

- lower secondary schools (General Secondary School): $40.2 \%$ of pupils (ages 10 to 14 )

The pupils of the lower secondary school who participated in the project attend a so-called New Middle School NMS (Neue Mittelschule). The curriculum, the pedagogical concept, and the performance appraisal (Leistungsbeurteilung) differ between two types of lower secondary school: New Middle School and General Secondary School (AHS) (allgemein bildende höhere Schule). After graduating from NMS, pupils can continue their studies in an AHS, to complete their A-Level exams. This is critical because only the AHS allows pupils to continue into further educational programs after compulsory school (Pflichtschule) (for further information, see Austria, Bundesministerium ... , 2018, "Die neue Mittelschule"). In Austria, Germany, and Switzerland, children are separated into different school types at the age of ten (that is, they are separated much earlier than in other countries). The underlying idea behind this separation is the goal of streaming based on pupils' performances at school, homogenizing the pupil population at the different school types (Herzog-Punzenberger, 2012). The statistical overview indicates a clear gap between the proportion of pupils using languages other than German in their family surroundings in NMS and AHS, respectively. As indicated above, language barriers are considered a major factor in early school-dropout. Therefore, pupils who do not have high competences in German (but maybe in other languages) usually struggle to proceed into higher education. Accordingly, the rate of early school-dropout is particularly high among pupils who speak a language or languages other than German in their family environment in Vienna. In 2015/16: $12.2 \%$ of those who use languages other than German in their family surroundings did not proceed into further educational programs, compared to $4.9 \%$ of 14-year-old pupils who only use German (Austria, Statistik Austria, 2019). Furthermore, $30.2 \%$ of the pupils with a migratory background interrupted their educational program, compared to $9.7 \%$ of the pupils without a migratory background (Steiner, Pessl, \& Bruneforth, 2015). However, these numbers can only serve as a point of reference, because a migratory background does not necessarily lead to different linguistic repertoires because of German speaking people migrating to Austria. Moreover, so-called secondgeneration pupils (that is, pupils who were born in Austria from one-or 
two - foreign-born parents) have adopted German as their family language (Herzog-Punzenberg, 2017).

It is noteworthy that the Austrian school system usually focuses on highly prestigious languages such as German, English, French, Italian, or Spanish. For the most part, supplementary language courses in schools concentrate on fostering the national language and language of education, German, or only the high-prestige languages mentioned above (Plutzar, 2009). Significantly, the languages in the pupils' linguistic repertoires rarely correspond to the languages in focus. Most pupils know languages such as Bosnian/Croatian/Serbian, Turkish, Albanian, Polish, or Romanian instead. When pupils start to attend primary school, their broad plurilingual competences begin to dwindle and continue to do so over their school career, because they barely get the chance to use them at school (Blommaert, Collins, \& Slembrouck, 2005). Nonetheless, mother tongue education is offered as extra-curricular activity called Freifach in a few Austrian schools. In 2017/18, merely 14.5\% of the plurilingual pupils in Austria participated in mother tongue education. In Vienna, this rate is the highest, with $19.3 \% .^{3}$

In our project, open spaces for pupils' linguistic resources were created in regular classroom education. By encouraging translanguaging, all the different languages could be used, without the necessity of having a teacher who knows all those languages, which would not have been possible due to the high linguistic diversity in Vienna. We took a closer look at the linguistic repertoires of the pupils involved in this project. At the beginning of the school year (September) and the end of the winter term (February), we asked them to indicate in a questionnaire which languages they could speak, write, listen to, and/or read. Figures 1 and 2 summarize the results. The questionnaire was developed for a larger study. In this article, it is referenced only in order to characterize the linguistic heterogeneity of the two classes.

Figure 1 shows that most pupils indicated they knew Bosnian, Croatian, Serbian, or Turkish besides German, the national language and language of education, as well as English, which they start to learn in primary school or sometimes even in preschool. Also, we see that many languages are spoken by just one or two pupils. Figure 2, based on the data gathered in the lower secondary school, provides a similar picture. Because several pupils dropped out of school in the course of that school year, the total numbers resulting from the first survey (September) differ slightly from those of the second questionnaire (February).

\footnotetext{
${ }^{3}$ In primary schools, the percentages are $24.6 \%$ in Austria and $33.6 \%$ in Vienna. In lower secondary schools, it is $7.4 \%$ in Austria and $10.6 \%$ in Vienna (Austria, Bundesministerium ... 2018, "Schule mehrsprachig").
} 


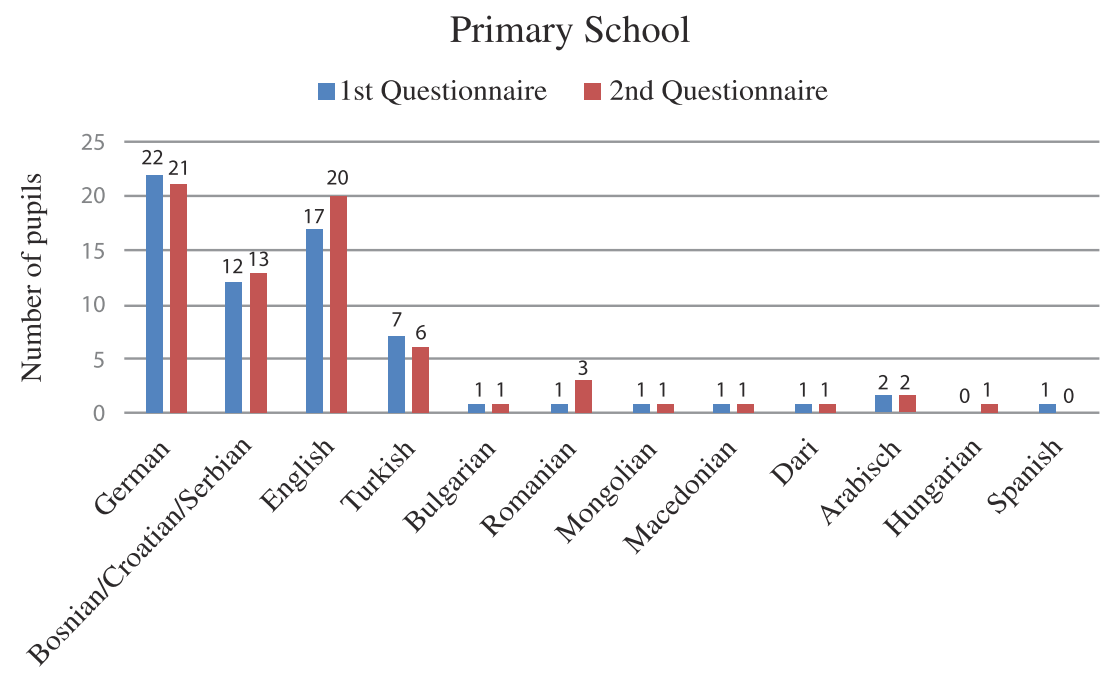

Figure 1

Languages the primary school pupils know (Schwarzl, forthcoming)

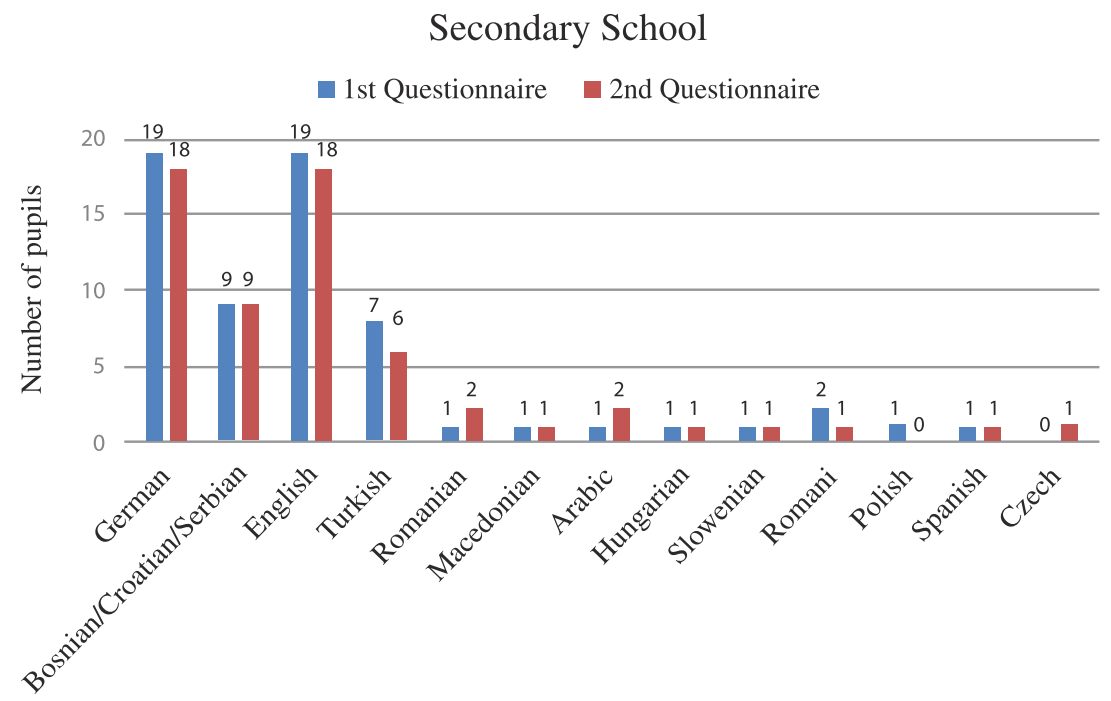

Figure 2

Languages the lower secondary school pupils know (Schwarzl, forthcoming) 


\section{Primary School}

$\square$ 1st Questionnaire $\quad$ 2nd Questionnaire
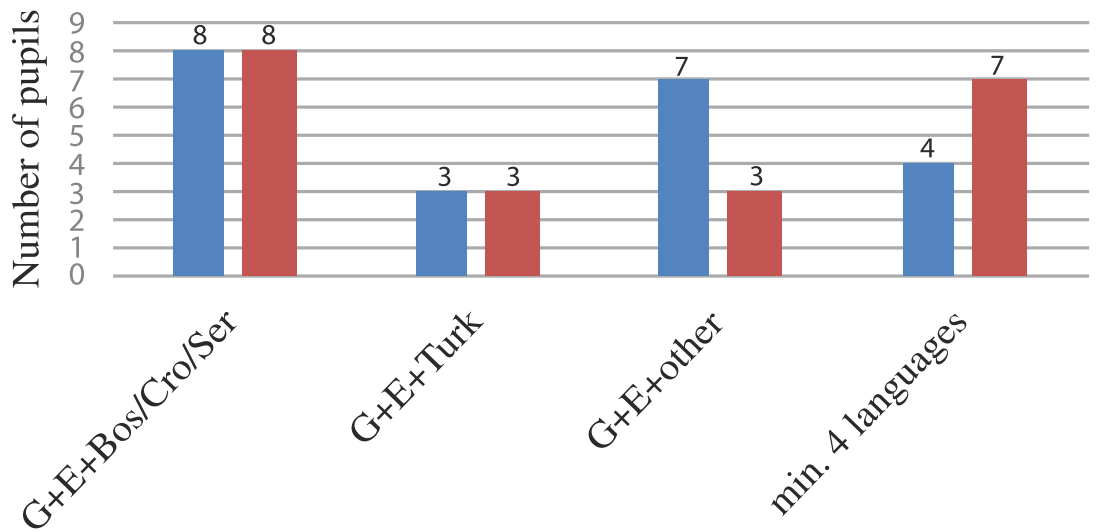

Figure 3

Linguistic repertoires of the primary school pupils (Schwarzl, forthcoming)

\section{SecondarySchool}

1st Questionnaire $\square$ 2nd Questionnaire

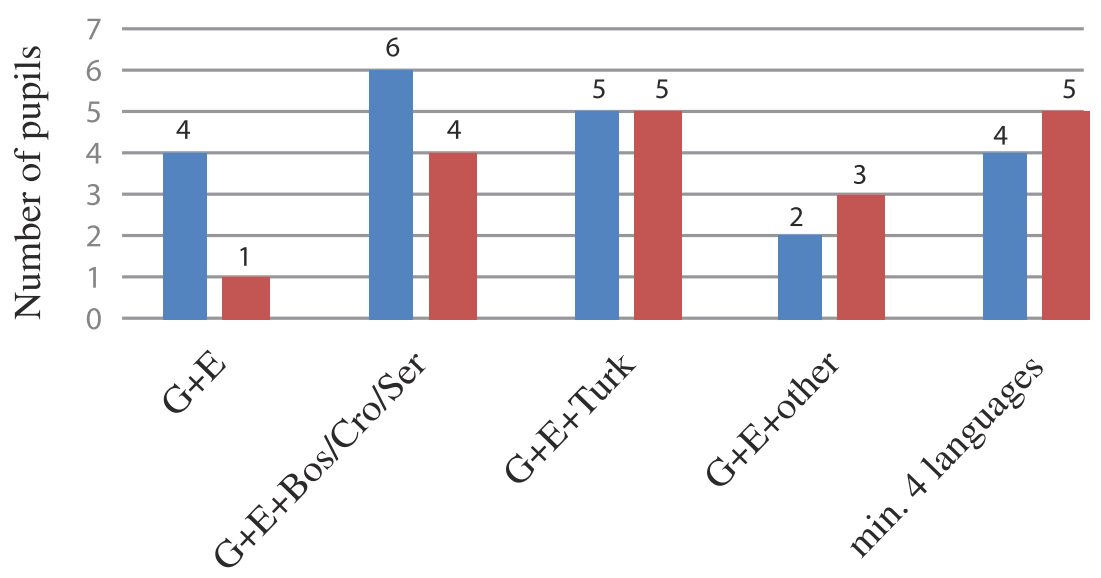

Figure 4

Linguistic repertoires of the secondary school pupils (Schwarzl, forthcoming) 
In the next section, we look at the linguistic repertoires shared by the pupils of the two classes. As we can see in Figures 3 and 4, pupils in both classes most frequently indicated that they knew German and English, as well as Bosnian, Croatian, or Serbian. The combination of German, English, and Turkish is also frequent. A small number of pupils indicated knowing German, English, and a language other than Bosnian, Croatian, Serbian, or Turkish. Moreover, a remarkably high number of pupils knew a minimum of four languages. Looking closer into this category, we found that, except for one pupil in the lower secondary school, all the pupils who know four languages indicated German, English, Bosnian, Croatian, Serbian, and/or Turkish, and/or one of the rare languages (i.e., languages that only one or two pupils have in their repertoire; see Figures 1 and 2). Notably, in the second survey, more pupils than in the first survey indicated that they knew languages other than German, English, or Turkish, or that they knew English. In the course of the ethnographic observation, we found evidence that, at the beginning of the project, many pupils did not know the names for some languages they were using (e.g., Hungarian and Romanian); this is why we notice a slight upward trend in the cases of Arabic and Romanian in Figure 2 and the cases of Bosnian, English, Romanian, and Hungarian in Figure 1. For example, a boy who had come to Austria from Afghanistan in 2016 first indicated that his mother tongue was Farsi. We offered him texts in Farsi for reading, but also in Persian, Arabic, and Dari, which led him to discover that his mother tongue is actually Dari and not Farsi. It seems that the focus on languages during the project also raised the pupils' awareness of different languages.

\section{The research design}

During the intervention of six months, we regularly conducted ethnographic observations of classroom education and breaks (from two to four times a week for at least three hours). We recorded our experiences in the form of field notes, which were subsequently analyzed by developing deductive and inductive categories, and then compacted into a thick description (Geertz, 2006). This method aims at obtaining a very rich and detailed description of the field, structured along the themes identified within the process of applying and developing categories (Geertz, 2006). The interviews were conducted with one teacher of each school class, transcribed with Exmaralda using the HIAT convention (Ehlich \& Redder, 1994; see Appendix) and analyzed using Content Analysis (Mayring, 2015). As stated in the previous section, the study reported here is part of a larger research project, in which the two interviews were first analyzed with a content analytical approach. During content analysis, we became aware of interesting linguistic features, which led us to analyze them a second time using Critical Discourse Analysis. However, this stage of analysis 
has not been completed at the time of writing, and we therefore focus on the outcomes of the Content Analysis here, but show passages of the interviews already transcribed in greater linguistic detail. For the interviews, we asked the teachers who used pedagogical translanguaging and the plurilingual texts most frequently in class. In Austrian primary schools, one teacher constantly stays with one class and carries out all the lessons; consequently, in the primary school we interviewed this teacher. Since, in lower secondary schools, each subject is usually taught by a different teacher, which means that classes have different teachers for each subject, we selected the music teacher, who was the only teacher beside the sociology teacher to integrate pupils' family languages intensively.

\section{Analysis of the field notes}

First, we want to briefly describe the two schools' overall approach to language, which was documented through the process of ethnographic research. In the cooperating primary school, colorful posters in various languages draw attention as one enters the school building, and it is noticeable that these languages are often linked to specific nations and cultures. The school offers integrative mother tongue education in Bosnian, Croatian, Serbian, and Turkish, which means that a mother tongue teacher for those languages gives some lessons together with another teacher in order to integrate those languages into regular lessons. During the observations, they were perceived as assistant teachers, helping pupils with various tasks but mostly using German. In the cooperating lower secondary school, pupils' linguistic diversity is not made explicitly visible, and there seems to be no focus on languages. A critical incident in the New Middle School during a break revealed that the school might even have a restrictive language policy. As we were sitting in front of the teachers' room, waiting for one of the collaborating teachers, one pupil spoke to another in a language other than German (we could not make out which language it was). As the speaking pupil saw us, he hesitated and justified his language usage to us by claiming that he was not using German only because the other pupil could not fully understand it. Neither on the school website nor in the linguistic landscape of the school did we find visible evidence for a restrictive language policy. In contradiction to her extensive use of pupils' family languages during her lessons, the music teacher in her interview also explained that, in her mind, languages other than the language of schooling (i.e., children's mother tongues) should be spoken exclusively in their family surroundings. Restrictive school policies that demand the use of German during breaks have indeed been proposed by some political stakeholders in Austria (HerzogPunzenberger, 2012).

In both classes, teachers for the most part organized their plurilingual 
lessons by using the plurilingual texts or texts in different languages we had provided. We show that children who know the languages more frequently used in those texts (Bosnian, Croatian, Serbian, and Turkish) were also given more opportunities to participate in lessons based on translanguaging. As pointed out with respect to the linguistic diversity of Viennese pupils, most pupils know Bosnian, Croatian, Serbian, or Turkish, but the linguistic diversity in the participating classes was very high: indeed, there were also pupils who knew other languages (i.e., languages that were not equally focused on by the teachers during the intervention). In fact, we based our project on translanguaging precisely because translanguaging pedagogy is the best framework for engaging with the linguistic diversity of Viennese pupils and creating open spaces for their linguistic resources. Although we worked intensively with the participating teachers, they did not fully adopt the translanguaging stance. Nevertheless, there were a few situations in which teachers created those open spaces for all the linguistic resources in class.

In a mathematics class in primary school, for example, pupils were practicing calculations in their workbooks when the teacher asked them to try to formulate sentences which answered text-based calculations in any language(s) they wanted. In this lesson, thus, everyone was given the opportunity to participate, but on the whole they focused on text-based input in some of the pupils' family languages, rarely creating open spaces for other languages. In other situations, pedagogical translanguaging was repeatedly used when there were children in class who were new learners of German. Teachers then used translanguaging strategically to help those children to make sense of the content by means of asking another child, who shared the same family language, for help. Clearly, this method is only possible if there are at least two pupils in class with a common family language. During another mathematics class in the primary school, the teacher asked a girl from Serbia, who had come to Austria a few months ago and had low competences in German, to sit next to a boy who obviously had high competences in Serbian and German. The teacher asked the boy to explain to her how the calculations work in Serbian, and he did so. Moreover, the teacher asked her to give her results in Serbian in front of the class and asked the boy to verify if they were correct. However, the teacher did not repeat what the numbers are called in German, which would probably have been useful for the girl. In biology lessons, spontaneous translanguaging for meaning-making purposes was frequently used by groups of pupils who shared the same family language(s). We noticed that pupils often struggled with biological jargon and used spontaneous translanguaging in these situations to make sense of the content. The biology teacher refused to use translanguaging and the plurilingual texts in his lessons, and he was not aware that pupils were using their family languages when they chatted with 
each other during lessons, especially when they could not understand jargon. In the course of the intervention, it became clear that pupils seemed to enjoy lessons (music and sociology) in which pedagogical translanguaging was used more than monolingual ones. This was evident when pupils participated more actively during lessons or when they communicated to the teacher that they did not want to end a plurilingual activity, such as singing a song or reading a text in languages other than German. Sometimes, pupils also discussed similar meanings of words in different languages and seemed motivated to translate words or even passages from one language into another.

From the very beginning of our observations in the primary school, we noticed that there were some pupils who acted cautiously when it came to using their family languages in front of the class. Mostly, pupils with seemingly high competences in their family language(s) acted more confidently in lessons in which planned translanguaging was used. Those confident pupils, who gained mastery experience, sometimes also indirectly encouraged other pupils to use their linguistic repertoires, simply because they had dared to use it before. Those situations were classified by us as vicarious experiences which could positively influence pupils' self-efficacy beliefs. In other classroom situations, we observed that some pupils talked about their emotional upheaval, describing feelings of anxiety and insecurity, because they perceived their linguistic repertoires as being too small in comparison to other pupils' repertoires. There were many situations in which pupils seemed annoyed and told the teacher they felt uncomfortable due to knowing, for example, only German, English, and Polish rather than two additional languages. Although teachers tried to use verbal persuasion, by telling them to be proud of the linguistic resources they had, similar situations were observed throughout the intervention. Often, pupils and/or teachers also applauded when pupils used their family languages in front of the class; this was classified as non-verbal persuasion.

At the beginning of the intervention, the sociology teacher in the lower secondary school decided to do language portraits with the children in order to make their linguistic repertoires visible in class. In applied linguistics, language portraits are often used in research that focusses on language biographies and plurilingualism in school contexts (Busch, 2006; Krumm, 2001; Schwarzl, Vetter, \& Janik, 2019). Using language portraits, people are asked to design, for example, a body silhouette while thinking about their linguistic repertoires (Krumm, 2010). In the lesson we observed, the teacher also told the pupils that they were free to present their portrait in front of the class when everyone had finished painting. It was striking that, again, there were a few pupils who acted very confidently about their linguistic resources, indicating that they knew a dominant language and/or that they had repertoires consisting of at least four languages. We are not in a position to assess whether their linguistic compe- 
tences were, in fact, higher than those of other pupils. However, we could deduce that their self-efficacy beliefs with respect to their repertoires were probably higher than those of pupils acting less confidently. Herzog-Punzenberger (2012) emphasizes that some languages in Austria suffer from very low prestige, which is why pupils often describe experiencing feelings of embarrassment when using those languages at school. On the one hand, using activities like this might allow pupils to gain mastery or vicarious experience; on the other hand, social comparison could probably also lead to lower self-efficacy beliefs for some children. In conclusion, we identified a strong dichotomy in our research, because pupils could not benefit equally from the intervention due to the existence of dominant languages in class and the teachers' focus on those languages.

\section{Analysis of the interviews}

In the collaborating New Middle School, we approached the music teacher for an interview, because she was the only teacher who intensively used pupils' linguistic resources during lessons. According to García, translanguaging pedagogies are still regarded with skepticism because the ideology underlying the separation of languages remains an issue (García, 2017).

We conducted a considerable number of ethnographic observations (altogether 76 hours) in the German, biology, and geography teachers' classes as well and also talked to them during breaks. We realized that managing discipline in class was difficult for them. Students were very noisy and agitated, and they did not calm down and listen to what teachers said to them. When we asked the teachers why they did not want to integrate pupils' linguistic resources into their lessons, they responded that it would be impossible to do so due to the pupils' behavior. Nevertheless, spontaneous translanguaging was observed regularly. The teachers stressed that using languages other than German in class would lead to a loss of control, because they would not understand everything pupils would be saying. We tried to support and encourage them, even conducting a plurilingual lesson by ourselves which was observed by the teachers. Conducting a plurilingual lesson by ourselves was not part of the initial plan. However, when we learned that some of the teachers would not conduct plurilingual lessons, we tried to support them by directly showing them how such lessons could work. Nonetheless, the lessons of the music teacher (sometimes, she also held the music lessons together with the sociology teacher) and the sociology lessons of the sociology teacher remained the only exception, and discipline was also better in their lessons. The pupils were very active, and they managed to control them by letting them stand up at the beginning of each lesson and doing some relaxing tasks with them. Moreover, they acted more calmly with the children than other teachers we observed. The 
children genuinely seemed to enjoy singing, and the guitar playing of the music teacher further contributed to the more relaxed atmosphere. Interestingly, at the beginning of the interview she seemed to be surprised that pupils really enjoyed her plurilingual lessons, as indicated in the quote below. In fact, during the ethnographic observations we also noticed pupils' motivation to participate in the lessons and the joy they expressed at being able to use their linguistic repertoires in class.

Also dass es derartig gut funktioniert, das hatt ich auch nicht erwartet. Das i:rgendwas rauskommt, joo-, hab ich gehofft, $\bullet$ aber dass es derartig gut funktioniert hab ich nīcht geglaubt.

[So, that it would work so well, I did not expect that. That s:omething welcome would come of it, yaa - I I hoped so, $\bullet$ but I did not believe that it would work so well.]

In the following excerpt from the interview, she talks about her past experiences with using pupils' family languages in classroom interaction and explains how negative those had been.

Des ist nicht selbstverständlich, dass die Schüle:r $\bullet$ ahh mit so aner Begeisterung mitmachen. $・$ Des kommt nicht so oft vor... manchmal sagen sie wäähh ... Ode:r, "Wir können das nicht", oder, so irgendwas. ((ea)) So ähnliche Sachen hob ich früher auch schon gemacht, das hat manchmal • überhaupt ned funktioniert... Weil sies abgelehnt haben. •.• [((lauter)) Ūnd weil sies zum Teil auch gar nicht] $\bullet$ zusammengebracht haben.

[It must not be taken for granted that pupils $\bullet$ uhm participate with such enthusiasm •• It does not occur so often... sometimes they say wäähh... O:r, "We cannot do that", or, something like that. ((ea)) Some time ago I tried similar stuff, sometimes this did $\bullet$ not work at all... Because they refused it. $\cdots$ [((louder) $)$ And because some of them even] $•$ did not manage to do it.]

We asked her if she had noticed any differences regarding the degree of the children's participation during plurilingual lessons. In the quote below, she briefly mentions that pupils with (a) mother tongue(s) not shared by other pupils struggle in plurilingual lessons. She did not elaborate her comment, but, as we described in the previous section, ethnographic observations also indicated that it is difficult for teachers to accommodate the high linguistic diversity.

- - schwer getan haben sich vor allem die Kinder, d:ie mit īhrer Muttersprache mehr oder weniger alleine sind. $\bullet$ So dass es keine $\bullet$ Grūppe gegeben hat.

$[\bullet-$ especially those children struggled w:ho are more or less alone with their mother tongue. $\bullet$ So that there was $\bullet$ no group.] 
In the previous section, we also emphasized the observation that perhaps not all pupils were able to benefit from the intervention - something that the primary school teacher seemed not to have noticed. In the following excerpt from the interview, but also during other conversations with the primary school teacher, we noticed that the appreciation of languages plays a decisive role for the teacher.

Ich glaub, die Kind:er, ähm fühlen sich vielmehr wertgeschätzt, wenn man ihre eigenen Muttersprachen immer wieder einbaut, und sie sind richtig stolz bei/in gewissen Unterrichtsfächern dann auch auf der eigenen Sprache was erklären zu können, oder auch nur zusammenzufassen, oder den anderen zu erzählen oder, ja, ...

[I think the child:ren uhm feel much more appreciated if their own mother tongues are used from time to time in class, and they are really proud in/during certain lessons when they can explain something in their own language, or even just summarize something, or tell someone, or, ya, ...]

Due to the high diversity in Viennese classrooms, there are often children who have no other children to talk to in their home language(s). In the previous comment of the lower secondary school teacher, we saw that she did, in fact, notice that those pupils are disadvantaged.

Furthermore, the primary school teacher mentioned that using translanguaging pedagogy helped the pupils to appreciate languages as important resources, neglecting the fact that pupils in her class sometimes acted differently. We could observe that pupils regarded languages that were not actively integrated into the lessons by the teacher as languages with very low prestige. Significantly, those languages were the ones that only one or two pupil(s) knew. Unfortunately, fewer (or no) texts were available in these languages. Thus, again, the pupils benefited from the intervention to varying degrees, depending on their linguistic repertoires.

ich glaub das ist $\bullet(($ aa $))$ was gñz gānz Wichtiges, dass die Kinder irgendwie sich selbst akzeptieren [((schneller)) und die anderen auch akzeptieren.] $\bullet$ Ähm •.• [((leiser)) das funktioniert auch gut über die Sprachen.] Weil sie lernen, dass jede Sprache wertvoll ist, egal welche Sprache es ist.... Es gibt auch viele Kinder, die sich die Trios dann mit nach Hause nehmen und zu Hause nochmal mit den Geschwistern od:er/oder Eltern durchlesen und das ist, allein dass die Eltern auch sehen, dass man, $\bullet$ weiß nicht, das wertschätzt ist glaub ich auch sehr wichtig. Und trōtzdem, es hat sich auch viel für die Klassengemeinschaft beigetragen und auch für ja $\cdots \cdot$ die Selbstakzepta/Selbstakzeptanz der Kinder, glaub ich, hats auch sehr viel gebrācht.

[I think this is $\bullet(($ aa $))$ something very very important that the children somehow accept themselves [((faster) $)$ and also accept the others.] • • Uhm • • $[(($ more quietly $))$ this also works well using languages.] Because they learn 
that every language is valuable, no matter which language it is.... There are also many children who then take the Trios home and read them again with their siblings o:r/or or with their parents and that is, if only that the parents also see that we, $\bullet$ I don't know, appreciate that is I think also very important. And still, it has also positively contributed much to the class community and also for ya $\cdots$ the children accept/accepting themselves, I think, it has also contributed a lot.

These brief insights from the interviews revealed how some of our observations are perceived by the two teachers. The appreciation of children's linguistic resources in the primary school is very much reflected in the interview with the primary school teacher; nevertheless, she does not acknowledge the fact that not all pupils could equally benefit from the intervention. Moreover, the music teacher's explanation of how surprised she was by the children's positive reaction to translanguaging pedagogies highlights her own skepticism towards translanguaging pedagogies, which is likely due to the ideologies underlying the separation of languages (García, 2017). At the same time, she noticed the previously discussed dichotomy between positive and negative effects of the intervention, although without elaborating on her comment in detail.

\section{Conclusion}

Both teachers and the school's pedagogical commitment to plurilingualism play a decisive role in successfully creating situations in which pupils can use their plurilingual competences. Rosiers (2017) also reports the decisive role of the teacher in creating spaces for translanguaging in two linguistically diverse school classes in Ghent and Brussels, Belgium, and finds that translanguaging practices used in the classroom mirror schools' language policies. However, the high linguistic diversity of children in Viennese primary and lower secondary schools presents a challenge for implementing translanguaging pedagogies that have benefited pupils in less diverse contexts (i.e., contexts in which mostly two languages, English and Spanish, co-occur; Lasagabaster \& García, 2014). A small number of studies concentrate on the implementation of translanguaging pedagogies with linguistically more heterogeneous student populations. For example, Woodley and Brown (2016) describe how Andrew Brown, a teacher in Queens, New York, implemented translanguaging pedagogy in his highly linguistically diverse fifth grade classroom (twenty-seven pupils and eight different mother tongues), after he had participated in CUNYNYSIEB (City University of New York-New York State Initiative on Emergent Bilinguals $)^{4}$ seminars on translanguaging. Woodley and Brown elaborate on various positive aspects of translanguaging pedagogy, such as building confidence and positive attitudes towards family languages and diversity, literacy

\footnotetext{
4 www.cuny-nysieb.org
} 
in pupils' family languages, deeper understanding of content, and increased interest for different languages and cultures. Possible negative aspects for a small number of pupils (that is, for those who know languages no other pupil in class knows) are not mentioned in the cited article. Our research, on the one hand, also found that translanguaging pedagogy had beneficial effects on pupils' self-efficacy beliefs, motivation, group dynamic, and their awareness of different languages. On the other hand, we also found negative consequences of the intervention for pupils who have unique or less valued linguistic resources (that is, those languages that are quantitatively not well represented in class and for which only a few or no texts are available for teaching). This finding contributes to the research literature on translanguaging in that it shows how translanguaging pedagogy can be both beneficial and harmful, depending on the extent to which plurilingual competences are shared and valued.

\section{References}

Austria. Bundesministerium für Bildung, Wissenschaft, und Forschung [Federal Ministry of Education]. (2018, 6 Apr.). Die neue Mittelschule. bildung.bmbwf.gv.at/schulen/ bw/nms/index.html

Austria, Bundesministerium für Bildung, Wissenschaft, und Forschung [Federal Ministry of Education]. (n.d.). Schule mehrsprachig [Multilingual school]. www.schule-mehrsprachig.at

Austria. Statistik Austria. (2019, 22 Aug.). Schulbesuch [School attendance]. www. statistik.at/web_de/statistiken/menschen_und_gesellschaft/bildung/schulen/schulbesuch/index. html

Bandura, A. (1995). Self-efficacy in changing societies. Cambridge: Cambridge University Press.

Bandura, A. (1997). Self-efficacy: The exercise of control. New York: Freeman.

Blommaert, J., \& Backus, A. (2011) Repertoires revisited: Knowing language in superdiversity. Working Papers in Urban Language and Literacies, Paper 67. www.academia.edu/6365319/WP67_Blommaert_and_Backus_2011._Repertoires_ revisited_Knowing_language_in_superdiversity

Blommaert, J., Collins, J., \& Slembrouck, S. (2005). Spaces of multilingualism. Language \& Communication, 25, 197-216.

Busch, B. (2006). Language biographies: Approaches to multilingualism in education and linguistic research. In B. Busch, A. Jardine, \& A. Tjoutuku (Eds.), Language biographies for multilingual learning (pp. 5-18). Cape Town: PRAESA.

Busch, B. (2017). Mehrsprachigkeit. Vienna: Facultas.

Cenoz, J. (2017). Translanguaging in school contexts: International perspectives. Journal of Language, Identity \& Education, 16, 193-198. 
Cenoz, J., Gorter, D., \& May, S. (Eds.). (2017). Encyclopedia of language and education: Language awareness and multilingualism (3rd ed.). Berlin: Springer.

Coste, D., Moore, D., \& Zarate, G. (2009). Plurilingual and pluricultural competence: Studies towards a Common European Framework of Reference for language learning and teaching. Strasbourg: Council of Europe, Language Policy Division. (Original French version published 1997). rm.coe.int/168069d29b

Council of Europe (CoE). (2001). Common European Framework of Reference for Languages: Learning, teaching, assessment. Strasbourg: Language Policy Unit. www. coe.int/en/web/common-european-framework-reference-languages

Ehlich, K., \& Redder A. (1994). Gesprochene Sprache: Transkripte und Tondokumente. Berlin: De Gruyter.

García, O. (2017) Translanguaging in schools: Subiendo y Bajando, Bajando y Subiendo as Afterword. Journal of Language, Identity \& Education, 16, 256-263.

García, O., \& Kleyn, T. (Eds.). (2016). Translanguaging with multilingual students: Learning from classroom moments. New York: Routledge.

Geertz, C. (2006). Dichte Beschreibung: Beiträge zum Verstehen kultureller Systeme. Frankfurt am Main: Suhrkamp. (Original work published 1983)

Gogolin, I. (2008). Der monolinguale "Habitus" der multilingualen Schule [The monolingual "Habitus" of the multilingual school] (2nd ed., unrevised). Münster, Germany: Waxmann Verlag.

Herzog-Punzenberger, B. (2012). Migration und Mehrsprachigkeit: Wie fit sind wir für die Vielfalt? Vienna: AK Wien.

Herzog-Punzenberger, B. (2017). Ungleichheit in der Einwanderungsgesellschaft: Intergenerationale Mobilität der angeworbenen Arbeitskäfte in Österreich. Wiesbaden, Germany: Springer.

Jerusalem, M. (2002). Selbstwirksamkeit und Motivationsprozesse in Bildungsinstitutionen. Weinheim, Germany: Beltz.

Krumm, H. (2001). Kinder und ihre Sprachen-lebendige Mehrsprachigkeit: Sprachenporträts. Vienna: Eviva.

Krumm, H. (2010). Mehrsprachigkeit in Sprachenportraits und Sprachbiographien von Migrantinnen und Migranten. AkDaF Rundbrief, 61, 16-24. [AkDaF = Arbeitskreis Deutsch als Fremdsprache]. www.akdaf.ch/html/rundbrief/rbpdfs/61_Mehrsprachigkeit_Sprachenportraits.pdf

Lasagabaster, D., García, O. (2014). Translanguaging: Towards a dynamic model of bilingualism at school. Culture and Education, 26, 557-572.

Marsh, H.W. (1987). The big-fish-little-pond effect on academic self-concept. Journal of Educational Psychology, 79, 280-295.

Mayring, P. (2015). Qualitative Inhaltsanalyse: Grundlagen und Techniken. Weinheim, Germany: Beltz. 
Plutzar, V., \& Kerschhofer-Puhalo, N. (dir.). (2009). Nachhaltige Sprachförderung Zur veränderten Aufgabe des Bildungswesens in einer Zuwanderergesellschaft: Bestandsaufnahmen und Perspektiven. Innsbruck: Studien-Verlag.

Rosiers, K. (2017). Unravelling translanguaging: The potential of translanguaging as a scaffold among teachers and pupils in superdiverse classrooms in Flemish education. In B. Paulsrud, J. Rosén, B. Straszer, \& A. Wedin (Eds.), New perspectives on translanguaging and education (pp. 149-169). Bristol: Multilingual Matters.

Schwarzer, R., \& Jerusalem, M. (2002). Das Konzept der Selbstwirksamkeit. Zeitschrift für Pädagogik [Supplement: Selbstwirksamkeit und Motivationsprozesse in Bildungsinstitutionen (Self-efficacy and motivational processes in educational institutions)], 44, 28-53.

Schwarzl, L. (forthcoming). Mehrsprachigkeit-von der Herausforderung zur Ressource: Mehrsprachige Materialien und Translanguaging im Klassenzimmer (Unpublished doctoral dissertation). University of Vienna.

Schwarzl, L., Vetter, E. \& Janik, M. (2019): Schools as linguistic space: Multilingual realities at schools in Vienna and Brno. In A. Kostoulas (Ed.), Challenging boundaries in language education. New York: Springer.

Woodley, H., \& Brown, A. (2016). Balancing windows and mirrors: Translanguaging in a linguistically diverse classroom. In O. García \& T. Kleyn (Eds.), Translanguaging with multilingual students: Learning from classroom moments (pp. 83-99). New York: Routledge. www.ecml.at/Portals/1/documents/ECML-resources/PlurCur-EN-final.pdf

\section{Appendix: Transcription key}

$\begin{array}{cl}- & \text { insertion } \\ \bullet & \text { very short pause } \\ \bullet & \text { pause }<0.5 \mathrm{sec} \\ \bullet \bullet & \text { pause }<1 \mathrm{sec} \\ : & \text { dilating sound }\end{array}$

\author{
diacritic steady \\ ((ea)) einatmen ('inhale') \\ ((aa) ausatmen ('exhale') \\ / no pause between words
}

